\title{
Population structure of jatropha and its implication for the breeding program
}

\author{
D.N. Santos ${ }^{1}$, J.L. Ferreira², M. Pasqual'1, A.L. Generoso³, T.A. Setotaw', \\ G.M.A. Cançado ${ }^{4}$ and W.A. Vendrame ${ }^{5}$
}

${ }^{1}$ Departamento de Agricultura, Universidade Federal de Lavras, Lavras, MG, Brasil 'Unidade Pecuária Sul, Empresa Brasileira de Pesquisa Agropecuária, Bagé, RS, Brasil

${ }^{3}$ Departamento de Genética,

Universidade Estadual do Norte Fluminense Darcy Ribeiro, Campos dos Goytacazes, RJ, Brasil

${ }^{4}$ Unidade Mista de Pesquisa em Genômica Aplicada a Mudanças Climáticas,

Empresa Brasileira de Pesquisa Agropecuária, Campinas, SP, Brasil

${ }^{5}$ Environmental Horticulture Department, Tropical Research and Education Center, University of Florida, Homestead, FL, USA

Corresponding author: D.N. Santos

E-mail: dalilhians@gmail.com

Genet. Mol. Res. 15 (1): gmr.15017770

Received October 2, 2015

Accepted November 16, 2015

Published March 24, 2016

DOI http://dx.doi.org/10.4238/gmr.15017770

ABSTRACT. Jatropha (Jatropha curcas L.) has potential as an oilseed crop that requires the development of technology for its exploitation. The objective of this study was to assess the population structure and the genetic diversity in jatropha accessions at a global level using simple sequence repeat $(S S R)$ molecular markers. Jatropha accessions $(N=109)$ from 10 countries were genotyped using 10 SSR markers. The results showed a low level of genetic diversity among 92 accessions originating from India, Mozambique, Ethiopia, Tanzania, Brazil, Honduras, and Indonesia, which were grouped in one cluster. In contrast, accessions from Mexico and Costa Rica showed high level of genetic variability. These accessions may be used to increase the genetic diversity of jatropha in the breeding 
populations. The study also showed the need of collecting activity from the center of diversity (Mexico and Costa Rica) to aggregate the genetic diversity in the international collections of jatropha.

Key words: Jatropha curcas; Physic nut; Microsatellite markers; Conservation; Genetic diversity

\section{INTRODUCTION}

Jatropha (Jatropha curcas L.) is a tropical species in the Euphorbiaceae. It is native to Mexico and Central America and distributed in Latin America, Africa, India, and South East Asia (Pandey et al., 2012). It is also classified as a source of high quality oil with biofuel potential, mainly biodiesel and bio jet fuel (Dias et al., 2012). This plant is widely recognized as a potential feedstock for biodiesel production (Pandey et al., 2012; Edrisi et al., 2015).

The cultivation and popularization of jatropha around the word have been mooted by three important ethos: i) achieving energy security, ii) revitalizing marginal and degraded lands (Biswas et al., 2010), and iii) alleviating rural poverty through employment and sustainable biofuel production (Edrisi et al., 2015). Due to these facts, jatropha is considered a plant with ecological and social appeal (Contran et al., 2013).

Among the many topics related to jatropha that have been discussed, the genetics continues to be of major interest. The literature agrees that jatropha shows high phenotypic variation. However, most of the genetic variability in J. curcas was shown to be essentially epigenetic, which causes phenotypic variation with no requirement of changing DNA sequences (Achten et al., 2010).

Different studies on various populations of jatropha have shown a low to moderate level of genetic variability (Sun et al., 2008; Gupta et al., 2012; Alves et al., 2013; Maghuly et al., 2015). This low variability is probably due to human impact including intensive selection, or the jatropha mating system (Alves et al., 2013; Bressan et al., 2013; Negussie et al., 2014).

The identification of the cause and absence of genetic variability in the germplasm bank and breeding populations of jatropha is an important step that will provide insight into future breeding programs of the species. In addition, it can help to identify the collections with high genetic variability that can be exploited to increase the genetic variation in the breeding process.

The study of genetic diversity can be done using molecular markers. These markers have an advantage over morphological markers because they are not affected by environmental factors (Basha and Sujatha, 2007) and may provide high quality information. Among the available molecular markers, microsatellites (simple sequence repeats - SSRs) are the most genetically stable, speciesspecific, and multi-allelic. Microsatellite regions are highly variable and polymorphic. Microsatellite markers are robust in their amplification and are widely used in the characterization of germplasm banks, including soybean (Qiu et al., 2013), olive (Cicatelli et al., 2013), grape (Salmaso et al., 2009), and jatropha. Sanou et al. (2015) used SSR markers to study the genetic diversity among jatropha accessions and concluded a high level similarity among them.

Maghuly et al. (2015) emphasized that one of the limitations in the jatropha breeding materials is the low or incomplete information about the germplasm resources. This highlights the importance of generating more information on the international jatropha collections, for a better exploitation of the species as an energy source that may benefit resource poor farmers. Increasing the genetic variation is a crucial step in any breeding program, which requires incorporating new sources of germplasm especially from the center of origin (Heller, 1996). 
Among the international collections of jatropha, the University of Florida gene bank contains various accessions of different origin. Therefore, studying the population structure and genetic diversity of this collection, using molecular markers, can provide insight into which part of the continent contains more variability, and can be exploited in future breeding programs, or can be targeted for further collection.

Therefore, the objective of this research is to study the population structure and genetic diversity of jatropha accessions on a global level, using SSR markers, as well as to identify the countries with most divergent jatropha populations.

\section{MATERIAL AND METHODS}

The experiments were conducted in the ornamental horticulture laboratory at the tropical research and education center (TREC), University of Florida, Homestead, FL, USA. The center is located at latitude $25.5^{\circ} \mathrm{N}$, longitude $80.4^{\circ} \mathrm{W}$ and at $1 \mathrm{~m}$ in altitude. The germplasm bank is kept at a subtropical climate, with an average annual temperature of $24^{\circ} \mathrm{C}$, maximum and minimum temperature of $29^{\circ}$ and $19^{\circ} \mathrm{C}$, respectively. The region receives $1473 \mathrm{~mm}$ rainfall annually.

The jatropha germplasm bank at TREC is comprised of 109 plants, representing 10 different countries. Within each country, different accessions were collected at different times indicated in Table 1 (e.g., Brazil 1, Brazil 2, etc).

\section{DNA extraction}

DNA extraction of the 109 jatropha accessions was performed using the DNeasy Plant Mini Kit (Qiagen Inc., Valencia, CA, USA). Samples consisting of $100 \mathrm{mg}$ young leaves were ground in liquid nitrogen and the extracts were poured into 2-mL microfuge tubes. To each microfuge tube, $400 \mu \mathrm{L}$ AP1 buffer and $4 \mu \mathrm{L}$ RNAse were added. The mixtures were incubated at $65^{\circ} \mathrm{C}$ for $10 \mathrm{~min}$ and mixed by inverting the tubes three times. Thereafter, $130 \mu \mathrm{L}$ AP2 buffer was added, the tubes were placed on ice for $5 \mathrm{~min}$ and then centrifuged at $18,894 \mathrm{~g}$ for $5 \mathrm{~min}$. The supernatant was removed and approximately $400 \mu \mathrm{L}$ was added to the column collector tube, which was centrifuged at 13,000 rpm for $5 \mathrm{~min}$. The supernatant was transferred to a new microfuge tube, to which AP3 buffer was added at 1.5 times its volume and the mixture was centrifuged at $8000 \mathrm{rpm}$ for $1 \mathrm{~min}$. The supernatant was discarded, the DNA retained on the column, which was transferred to a new microfuge tube. Then, $500 \mu \mathrm{L}$ AW buffer was added and the column was centrifuged at $8000 \mathrm{rpm}$ for 2 min. The column was transferred again to a new microfuge tube and $100 \mu \mathrm{L} A E$ buffer was added twice, yielding $200 \mu \mathrm{L}$ DNA solution. The DNA concentration of the samples was measured using a 2000/2000c NanoDrop spectrophotometer (Thermo Scientific, Wilmington, DE, USA) and all measurements were normalized to $15 \mathrm{ng}$ DNA.

\section{Genotyping with microsatellite markers}

For the genotyping, 10 markers previously shown to be polymorphic for J. curcas (Pamidimarri et al., 2009; Achten et al., 2010; Phumichai et al., 2011) were used. A detailed description of the primers is presented in Table 2. The expected sizes of the fragments were calculated based on the original sequences deposited in GenBank, where the SSR primers were designed and provided a means for consistency of results. 
Table 1. Jatropha (Jatropha curcas L.) germplasm collection at the Tropical Research and Education Center, University of Florida, Homestead, FL, USA. Accessions are indicated with their laboratory identifications (ID) and geographic origin.

\begin{tabular}{|c|c|c|c|c|c|}
\hline ID & Origin & ID & Origin & ID & Origin \\
\hline 1 & India 3 & 38 & India 2 & 75 & Brazil 2 \\
\hline 2 & India 4 & 39 & India 2 & 76 & Brazil 2 \\
\hline 3 & India 4 & 40 & Brazil 1 & 77 & Indonesia 2 \\
\hline 4 & India 4 & 41 & Brazil 1 & 78 & Indonesia 2 \\
\hline 5 & India 4 & 42 & India 3 & 79 & Indonesia 2 \\
\hline 6 & India 4 & 43 & India 3 & 80 & Indonesia 2 \\
\hline 7 & India 4 & 44 & India 3 & 81 & Indonesia 2 \\
\hline 8 & India 4 & 45 & Costa Rica & 82 & Indonesia 2 \\
\hline 9 & India 4 & 46 & Costa Rica & 83 & Indonesia 2 \\
\hline 10 & India 4 & 47 & Costa Rica & 84 & Indonesia 2 \\
\hline 11 & India 4 & 48 & Costa Rica & 85 & Indonesia 2 \\
\hline 12 & Mozambique & 49 & Costa Rica & 86 & Indonesia 1 \\
\hline 13 & Mozambique & 50 & Costa Rica & 87 & India 3 \\
\hline 14 & Mozambique & 51 & Costa Rica & 88 & India 3 \\
\hline 15 & Mozambique & 52 & Costa Rica & 89 & Tanzania \\
\hline 16 & Ethiopia & 53 & Costa Rica & 90 & Tanzania \\
\hline 17 & Ethiopia & 54 & Costa Rica & 91 & Tanzania \\
\hline 18 & Ethiopia & 55 & Costa Rica & 92 & Tanzania \\
\hline 19 & Ethiopia & 56 & Honduras & 93 & Tanzania \\
\hline 20 & Tanzania & 57 & Honduras & 94 & Tanzania \\
\hline 21 & India 3 & 58 & Honduras & 95 & Tanzania \\
\hline 22 & India 3 & 59 & Honduras & 96 & Tanzania \\
\hline 23 & Mexico & 60 & Brazil 1 & 97 & Tanzania \\
\hline 24 & Mexico & 61 & Brazil 1 & 98 & Tanzania \\
\hline 25 & Mexico & 62 & Brazil 1 & 99 & Brazil 3 \\
\hline 26 & Mexico & 63 & Brazil 1 & 100 & Brazil 3 \\
\hline 27 & Mexico & 64 & Brazil 1 & 101 & Brazil 4 \\
\hline 28 & Mexico & 65 & India 3 & 102 & Brazil 4 \\
\hline 29 & Mexico & 66 & India 3 & 103 & Brazil 4 \\
\hline 30 & Mexico & 67 & Brazil 2 & 104 & Brazil 4 \\
\hline 31 & Mexico & 68 & Brazil 2 & 105 & Brazil 4 \\
\hline 32 & Mexico & 69 & Brazil 2 & 106 & Brazil 4 \\
\hline 33 & Mexico & 70 & Brazil 2 & 107 & Brazil 4 \\
\hline 34 & India 1 & 71 & Brazil 2 & 108 & Brazil 4 \\
\hline 35 & Guatemala & 72 & Brazil 2 & 109 & India 3 \\
\hline 36 & Guatemala & 73 & Brazil 2 & & \\
\hline 37 & Guatemala & 74 & Brazil 2 & & \\
\hline
\end{tabular}

The amplification reactions were performed in a final volume of $20 \mu \mathrm{L}$ with $30 \mathrm{ng}$ DNA, 200 $\mu \mathrm{M}$ dNTP (Thermo Scientific), 8 pM M13F primer (forward-5'TGTAAAACGACGGCCAGTATGC3'), $32 \mathrm{pM}$ primer R (reverse), 32 pM M13 fluorescent 6-FAM (Eurofins MWG/Operon Huntsville, USA), $0.5 \mathrm{U}$ Taq polymerase (New England BioLabs, Ipswich, MA, USA), and $1.5 \mathrm{mM} \mathrm{MgCl}$ included in $1 \mathrm{X}$ buffer (New England BioLabs, Hitchin, England). The final volume $(20 \mu \mathrm{L})$ was achieved by addition of MilliQ water (Invitrogen, Life Technologies, Grand Island, NY, USA).

Amplifications followed the methodology described by Hufford et al. (2011), with modifications to the annealing temperature. The program consisted of an initial denaturation at $94^{\circ} \mathrm{C}$ for $5 \mathrm{~min}$ and 30 cycles of the following sequence: denaturation at $94^{\circ} \mathrm{C}$ for $30 \mathrm{~s}$, annealing at $54^{\circ} \mathrm{C}$ for $45 \mathrm{~s}$, and extension at $72^{\circ} \mathrm{C}$ for $45 \mathrm{~s}$. This was followed by eight cycles of the following sequence: denaturation at $94^{\circ} \mathrm{C}$ for $30 \mathrm{~s}$, annealing at $52^{\circ} \mathrm{C}$ for $45 \mathrm{~s}$, and extension at $72^{\circ} \mathrm{C}$ for 45 s. The final extension was done at $72^{\circ} \mathrm{C}$ for $10 \mathrm{~min}$. Amplifications were performed in a PTC-100 thermocycler (Bio-Rad, Hercules, CA, USA).

The presence of amplified fragments was confirmed on a 1\% agarose gel, dyed with $6 \mu \mathrm{L}$ 10,000X GelRed (Phenix Research, Candler, NC, USA) and visualized in a high UV performance transilluminator (UVP, Upland, CA, USA). After confirmation of amplification efficiency, 1:10 dilutions were made using MilliQ water. The samples were then placed in polystyrene boxes containing dry 
ice and shipped overnight to the interdisciplinary center for biotechnology research, University of Florida, Gainesville, FL, USA, for genetic analysis and genotyping. Prior to the genetic analysis, performed on an ABI 3730 sequencer, Hi-Di formamide and the weight marker GeneScan 600 LIZ (ThermoFisher Scientific, Grand Island, NE, USA) were added to the samples.

Table 2. Microsatellite primers for Jatropha curcas with their respective sequences, annealing temperatures (Tm), expected sizes (bp), and bibliographic references.

\begin{tabular}{|c|c|c|c|c|}
\hline Primer & Sequences & $\operatorname{Tm}\left({ }^{\circ} \mathrm{C}\right)$ & $\mathrm{bp}$ & Reference \\
\hline Jcps21 & $\begin{array}{l}\text { F: CCTGCTGACAGGCCATGATT } \\
\text { R: TTTCACTGCAGAGGTAGCTTGTATA }\end{array}$ & 54.8 & 190 & Achten et al., 2010 \\
\hline Jcds58 & $\begin{array}{l}\text { F: TCCATGAAGTTTGCTGGCAAT } \\
\text { R: AGGTCATCTGGTAAAGCCATACC }\end{array}$ & 54.0 & 109 & Achten et al., 2010 \\
\hline Jcps10 & $\begin{array}{l}\text { F: CATCAAATGCTAATGAAAGTACA } \\
\text { R: CACACCTAGCAAACTACTTGCA }\end{array}$ & 46.5 & 112 & Pamidimarri et al., 2009 \\
\hline Jcps24 & $\begin{array}{l}\text { F: GGATATGAAGTTTCATGGGACAAG } \\
\text { R: TTCATTGAATGGATGGTTGTAAGG }\end{array}$ & 51.0 & 204 & Pamidimarri et al., 2009 \\
\hline Jct27 & $\begin{array}{l}\text { F: GCCATTAGAATGGACGGCTA } \\
\text { R: TGCGTGAAGCTTTGATTTGA }\end{array}$ & 60.0 & 235 & Phumichai et al., 2011 \\
\hline Jcps20 & $\begin{array}{l}\text { F: ACAGCAAGTGCACAACAATCTCA } \\
\text { R: TACTGCAGATGGATGGCATGA }\end{array}$ & 55.0 & 224 & Achten et al., 2010 \\
\hline Jct15 & $\begin{array}{l}\text { F: AATTCTCTTTCCGCGATCCT } \\
\text { R: CGTAGACCTTCCAACAGCAA }\end{array}$ & 60.0 & 201 & Phumichai et al., 2011 \\
\hline Jct16 & $\begin{array}{l}\text { F: GCCTCCAGCATCTTTCAATC } \\
\text { R: AACAATCCCCATTCCTCCTC }\end{array}$ & 60.0 & 103 & Phumichai et al., 2011 \\
\hline Jct68 & $\begin{array}{l}\text { F: AGCGATAATCGGCCTACCTT } \\
\text { R: CAACGTCACTGCCTCCTACC }\end{array}$ & 60.0 & 212 & Phumichai et al., 2011 \\
\hline Jct81 & $\begin{array}{l}\text { F: CCATTTAGAACCACAACCAT } \\
\text { R: GATGTCCAATAAGCCTGAAT }\end{array}$ & 54.0 & 143 & Phumichai et al., 2011 \\
\hline
\end{tabular}

\section{Data analysis}

Data were tabulated from the allelic profiles of the 10 SSR markers derived from 109 jatropha accessions. First, a Bayesian model based cluster analysis was performed to determine the possible genetic structure using STRUCTURE v. 2.3.3 (Pritchard et al., 2000), as described in detail by Nunes et al. (2013). The appropriate number of clusters (K) was determined following the method proposed by Evanno et al. (2005) using Structure Harvester (Earl and vonHoldt, 2012). The polymorphic information content (PIC), which measures the ability of the primers to detect differences among the accessions analyzed, was estimated using PowerMarker v. 3.25 (Liu and Muse, 2005).

To understand the existing genetic diversity and population structure of collections from different regions of the world, a clustering analysis was performed using the unweighted pair group method with arithmetic mean (UPGMA) clustering method based on Cavalli-Sforza chord distance (Cavalli-Sforza and Edwards, 1967).

The principal coordinate analysis (PCoA) and molecular analysis of variance (AMOVA) (Excoffier et al., 2005) were performed using GenAlEx v. 6.41 (Peakall and Smouse, 2006).

\section{RESULTS}

The number of alleles produced per primer ranged from 1 to 7 . The estimated PICs showed high values for primers Jct27, Jct15, Jct16, Jct68, and Jct81. Among the 10 SSR markers, primer Jct68 provided the highest PIC value (0.4161) (data not shown). The cluster analysis grouped the 109 jatropha accessions into two groups $(\mathrm{K}=2)$ (Figure 1). The first group (Group 1; red), with 92 individuals, was formed by all jatropha plants from India, Mozambique, Ethiopia, Tanzania, Brazil, Honduras, and Indonesia, as well as one Mexican (ID 30) and four Costa Rican (ID 45, 50, 51, 
and 52) accessions. This indicates a close genetic relationship within the group. The second group (Group 2; green), comprised 17 accessions from Mexico and Costa Rica that showed a high level of genetic diversity. This group showed some level of admixture compared to the first group.
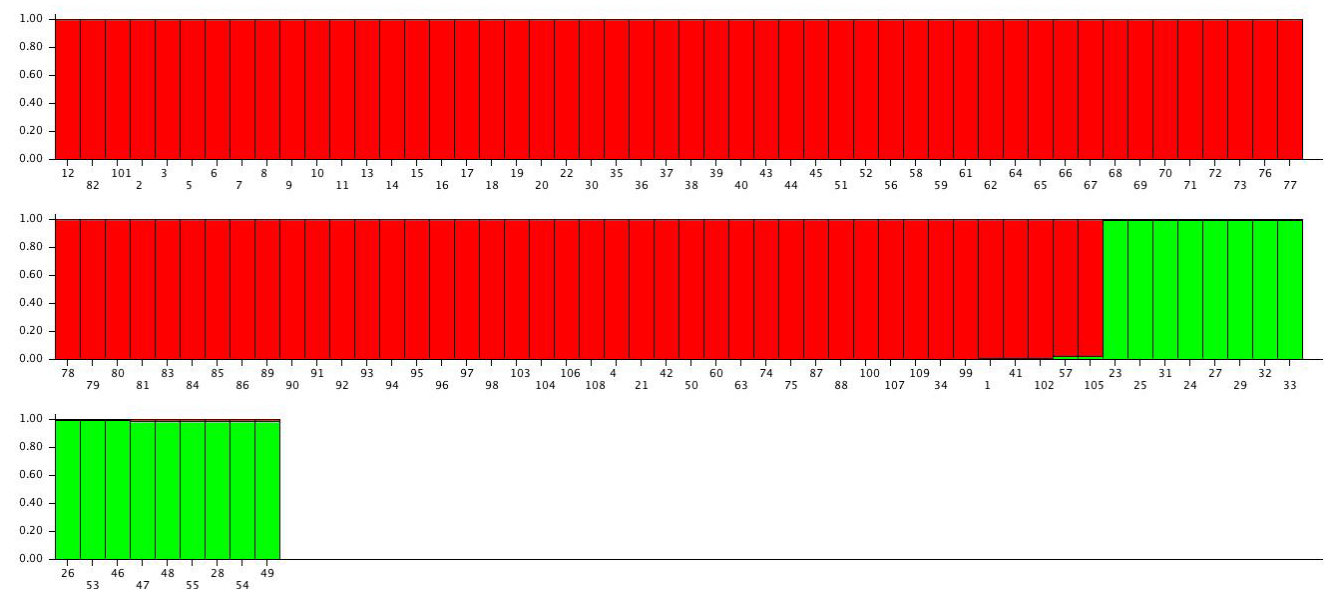

Figure 1. Analysis of the genetic structure of the 109 accessions of Jatropha curcas L. produced using Bayesian based clustering analysis using Structure v. 2.3.4. The numbers of the $\mathrm{x}$-axis represent the encoding of each accession following the description in Table 1. The red and green colors represent the group to which each individual belongs.

The PCoA (Figure 2) classified the 109 accessions into four groups, where the Costa Rican and Mexican accessions were relatively closer to each other, while maintaining distance from the other countries. In addition, the accessions from the other countries were classified into two groups where the first group contains the Brazilian, Tanzanian and Indonesian accessions (below the $x$-axis) and the rest grouped in the second cluster (above the $x$-axis). The first two principal coordinates explained $52.32 \%$ of the total variation, clearly classifying the accessions according to their place of origin (Figure 2).

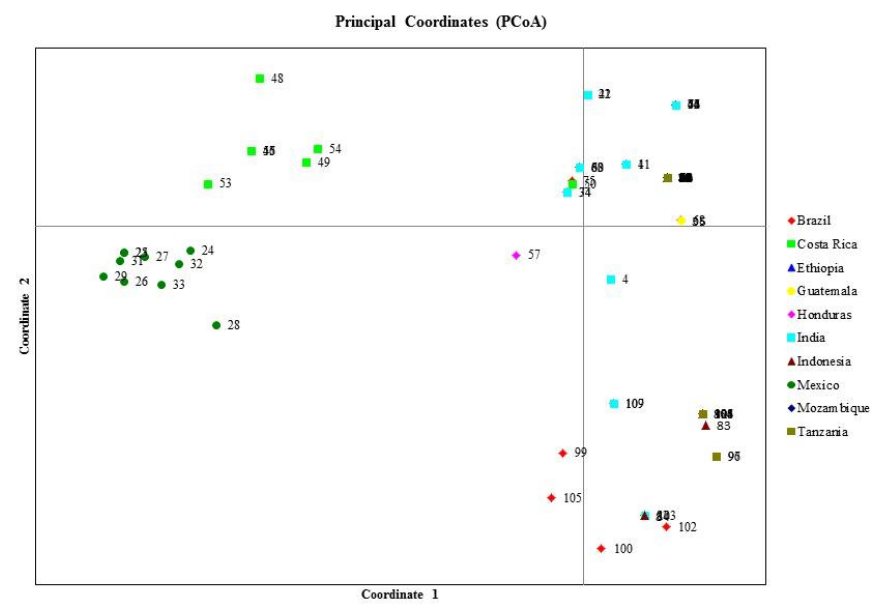

Figure 2. The results from the PCoA analysis for the 109 accessions of jatropha from the germplasm bank of University of Florida, obtained with 10 SSR markers. 
The phenetic tree of the 109 accessions based on the UPGMA (Figure 3), confirmed the grouping pattern reported in the PCoA. The dendrogram showed clear separation of the Costa Rican and Mexican accessions from the rest of the accessions, as presented in the PCoA (Figure 2 ), and showed a higher level of diversity than the accessions from other countries.

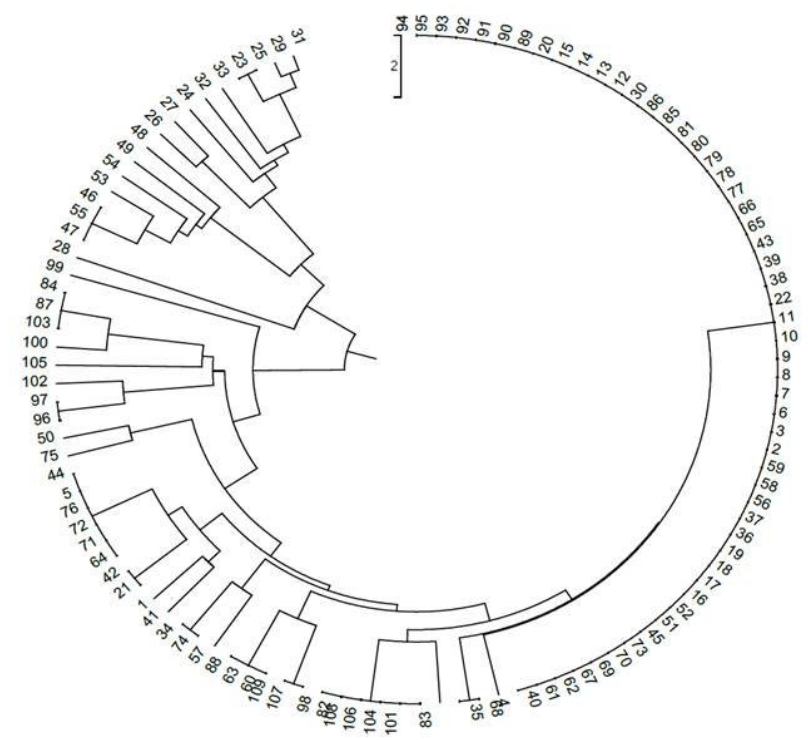

Figure 3. Phenetic UPGMA tree obtained by the 10 SSR markers based on Cavalli-Sforza chord distance (1967), showing the genetic relationships among the 109 accessions of the jatropha germplasm bank at the University of Florida. The edge numbers represent each accession as presented in Table 1.

Based on the place of origin (10 countries), the AMOVA showed that $65 \%$ of the total variation was within population and the rest, 35\%, among populations (Table 3). This showed some level of genetic variation among the accessions from some countries, especially Costa Rica and Mexico.

\section{Table 3. AMOVA of the 109 jatropha accessions.}

\begin{tabular}{l|c|c|c|c}
\hline Source of variation & d.f. & MSD & Estimated variance & Percentage of molecular variance \\
\hline Between groups & 9 & 18.149 & 1.496 & 35 \\
\hline Within groups & 98 & 2.812 & 2.812 & 65 \\
\hline Total & 108 & & 4.308 & 100 \\
\hline
\end{tabular}

\section{DISCUSSION}

The Bayesian cluster analysis classified the 109 accessions into two principal groups: the majority of the Mexican and the Costa Rican collections were allocated to the first group, whereas the other accessions clustered in the second group. This grouping indicated a low level of genetic diversity in the collections of jatropha in the world. Maghuly et al. (2015) and Sanou et al. (2015) also reported a low level of genetic diversity among accessions of jatropha from Africa, Asia, Central and South America.

The PCOA and UPGMA classified the accessions into four groups. These analyses classified the accessions in more detail and indicated the existence of some level of variability 
among accessions. The information obtained using the PCoA showed some level of variability among the accessions from Mexico and Costa Rica.

The observed variability is supported by the morphological evaluation reported in Nietsche et al. (2013). These authors evaluated 17 accessions of jatropha from the collection at the University of Florida and observed that the Mexican and Costa Rican accessions differed in reproductive characteristics. Costa Rican accessions have a higher number of female flowers and a higher frequency of pollen germination. Due to these superior features, these accessions were suggested as potential parents in crossing programs with the aim of developing cultivars. The clear separation of the Mexican and Costa Rican accessions from all other accessions indicates that these groups may contain unique genes produced through mutation related to their place of origin.

Our results also showed that the Costa Rican and Mexican accessions can be used as potential parents in breeding programs of jatropha because they showed a high level of genetic diversity. The high genetic diversity and distinctness of the Mexican accessions in this study, has also been observed in Pecina-Quintero et al. (2011). Therefore, the inclusion of Mexican and Costa Rican accessions in every country's national collections and breeding programs is recommended, to increase the genetic base of the breeding population.

We found that $65 \%$ of the total variation is partitioned within populations and $35 \%$ among populations, which indicated some level of differentiation among populations from different regions. The high level of within population variation is frequently observed in allogamous species (Maghuly et al., 2015). In accordance with our results, Bressan et al. (2013) found $68.3 \%$ outcrossing in jatropha species using SSR markers confirming that this species is allogamous. In addition, the dominance and efficiency of cross-fertilization in jatropha was reported by Raju and Ezradanam (2002) and Kaur et al. (2011), further supporting our own findings.

The low genetic diversity observed in this and other studies may be the result from the apomixis reproduction system, as reported in phytotechnical studies in jatropha (Bhattacharaya et al., 2005; Kaur et al., 2011), which potentially fixes the alleles at each locus and limits genetic recombination. In addition, using flow cytometry analysis, Ambrosi et al. (2010) reported the occurrence of non-gametophytic apomixis in jatropha.

The germplasm bank used in this study includes accessions from diverse geographical origins that are expected to show medium or high levels of genetic variability. However, this prediction was not supported in the present study. The results also showed that the accessions from continents outside of jatropha center of origin, with different soil and environmental conditions may not be able to create adaptive genes over time. The low genetic diversity observed can also be associated with the low number of alleles per locus obtained in this study (1-7 alleles). However, our results are in accordance with the findings reported in other studies of the same nature (Sanou et al., 2015; Maghuly et al., 2015). A similarly low number of alleles was also documented by Sharma and Chauhan (2011), who found 2-6 alleles by transferring the SSR castor primer to jatropha. Similarly, Na-Ek et al. (2011) observed 2-4 alleles per locus, and Bressan et al. (2012) found 2-8 alleles per locus from new SSR markers developed for jatropha.

The low genetic variability in jatropha may also be due to evolutionary processes. This species may have undergone genetic drift over time, both due to the founder effect and the effect of a bottleneck, leading to an increase in homogeneity. Jatropha suffered a founder effect during its dissemination to Asia and Africa by Portuguese navigators 400 years ago, due to the small sample size that was not representative of the original, natural population (Heller, 1996). The effect of a bottleneck occurs when the size of a population is drastically reduced due to the selection process (agronomic or not) driven by man (Veasey et al., 2011). The existence of human actions that 
reduced the population of jatropha is backed by Ambrosi et al. (2010), who claimed that jatropha was initially not selected for characteristics of productivity and/or quality. Thus, the selection process was poorly performed and reduced the size of the population, where the new accessions of jatropha originated from this group of selected plants.

The result of isolated environments colonized by very similar accessions is that, even with cross-fertilization, the formation of new variability will probably not be possible. This may have caused high genetic similarity among accessions of jatropha in the new habitats. This observation is also supported by our study, where the accessions collected from every country outside Mexico and Costa Rica showed low levels of genetic diversity and clustered in the same group as illustrated using different analysis methods. Thus, there was a decrease in the genetic variability of the new populations in relation to the original population. Bressan et al. (2013) also showed that a small number of individuals in the same location can result in a high rate of correlated mating, when the open-pollinated seeds were mainly full-sibs, as observed in this case.

Achten et al. (2010) also suggested that the complex history of introduction and domestication in other continents contributed to the low level of genetic variability observed in this species. The low level of admixture among the accessions of the jatropha observed in this study suggests that most accessions have developed from the same origin and have not produced any considerable change over time in its place of adaptation. Alternatively, jatropha requires more time to create new variability.

Other possible reasons may be the vegetative propagation method used by former farmers. According to Ovando-Medina et al. (2011), a vegetative propagation was used for centuries, to ensure the spread of jatropha in rural areas. Thus, a few selected accessions of jatropha have become widely spread clonally. The high level of similarity observed in this study also supports this conclusion, because most of the accessions clustered in one single group with a membership coefficient of $100 \%$ using Bayesian clustering analysis. One might also expect that these individuals remain highly related to each other across generations.

In general, the species' natural environment (in Mexico and Costa Rica) contains high levels of genetic diversity that may be exploited to enrich the germplasm bank and the breeding populations of this species. Therefore, the introduction of accessions from these regions may sustain future production of jatropha. This crop is an important source of income, especially for small-scale farmers that live in the semiarid regions of the tropics. The gain from the productivity of this crop can improve the livelihood of people living in the sub-tropical regions of the world, by providing an additional income source.

\section{Conflicts of interest}

The authors declare no conflict of interest.

\section{ACKNOWLEDGMENTS}

We thank Coordination for the Improvement of Higher Education Personnel (Coordenação de Aperfeiçoamento de Pessoal de Nível Superior - CAPES) for the opportunity to complete the doctorate degrees through the program Science without Borders. We thank National Council for Scientific and Technological Development (Conselho Nacional de Desenvolvimento Científico e Tecnológico - CNPq) and Minas Gerais State Research Foundation (Fundação de Amparo à Pesquisa do Estado de Minas Gerais - FAPEMIG) for providing national scholarships. We also 
thank Alba Myers for technical support in the laboratory, Vecenergy for financial support of the research at the University of Florida, and Ann Marie Clark of the University of Florida for performing the genotyping work.

\section{REFERENCES}

Achten WMJ, Nielsen LR, Aerts R, Lengkeek AG, et al. (2010). Towards domestication of Jatropha curcas. Biofuels 1: 91-107. http://dx.doi.org/10.4155/bfs.09.4

Alves AA, Bhering LL, Rosado TB, Laviola BG, et al. (2013). Joint analysis of phenotypic and molecular diversity provides new insights on the genetic variability of the Brazilian physic nut germplasm bank. Genet. Mol. Biol. 36: 371-381.http://dx.doi. org/10.1590/S1415-47572013005000033

Ambrosi DG, Galla G, Purelli M, Barbi T, et al. (2010). DNA Markers and FCSS analyses shed light on the genetic diversity and reproductive strategy of Jatropha curcas L. Diversity (Basel) 2: 810-836. http://dx.doi.org/10.3390/d2050810

Basha SD and Sujatha M (2007). Inter and intra-population variability of Jatropha curcas (L.) characterized by RAPD and ISSR markers and development of population-specific SCAR markers. Euphytica 156: 375-386. http://dx.doi.org/10.1007/ $\underline{\mathrm{s} 10681-007-9387-5}$

Bhattacharaya A, Kalyani D and Subodh KD (2005). Floral biology, floral resource constraints and pollination limitation in Jatropha curcas L. Pak. J. Biol. Sci. 8: 456-460. http://dx.doi.org/10.3923/pibs.2005.456.460

Biswas PK, Pohit S and Kumar R (2010). Biodiesel from jatropha: can India meet the $20 \%$ blending target? Energy Policy 38 : 1477-1484. http://dx.doi.org/10.1016/j.enpol.2009.11.029

Bressan E de A, Scotton DC, Ferreira RR, Jorge EC, et al. (2012). Development of microsatellite primers for Jatropha curcas (Euphorbiaceae) and transferability to congeners. Am. J. Bot. 99: e237-e239.http://dx.doi.org/10.3732/ajb.1100532

Bressan EA, Sebbenn AM, Ferreira RR, Lee TSG, et al. (2013). Jatropha curcas L. (Euphorbiaceae) exhibits a mixed mating system, high correlated mating and apomixis. Tree Genet. Genomes 9: 1089-1097. http://dx.doi.org/10.1007/s11295013-0623-y

Cavalli-Sforza LL and Edwards AWF (1967). Phylogenetic analysis. Models and estimation procedures. Am. J. Hum. Genet. 19: 233-257.

Cicatelli A, Fortunati T, De Feis I and Castiglione S (2013). Oil composition and genetic biodiversity of ancient and new olive (Olea europea L.) varieties and accessions of southern Italy. Plant Sci. 210: 82-92.http://dx.doi.org/10.1016/j. plantsci.2013.05.011

Contran N, Chessa L, Lubino M, Bellavite D, et al. (2013). State-of-the-art of the Jatropha curcas productive chain: from sowing to biodiesel and by-products. Ind. Crops Prod. 42: 202-215. http://dx.doi.org/10.1016/j.indcrop.2012.05.037

Dias LAS, Missio RF and Dias DCFS (2012). Antiquity, botany, origin and domestication of Jatropha curcas (Euphorbiaceae), a plant species with potential for biodiesel production. Genet. Mol. Res. 11: 2719-2728.http://dx.doi.org/10.4238/2012. June.25.6

Earl DA and vonHoldt BM (2012). STRUCTURE HARVESTER: a website and program for visualizing STRUCTURE output and implementing the Evanno method. Conserv. Genet. Resour. 4: 359-361. http://dx.doi.org/10.1007/s12686-011-9548-7

Edrisi SA, Dubey RK, Tripathi V, Bakshi M, et al. (2015). Jatropha curcas L.: a crucified plant waiting for resurgence. Renew. Sustain. Energy Rev. 41: 855-862. http://dx.doi.org/10.1016/j.rser.2014.08.082

Evanno G, Regnaut S and Goudet J (2005). Detecting the number of clusters of individuals using the software STRUCTURE: a simulation study. Mol. Ecol. 14: 2611-2620.http://dx.doi.org/10.1111/j.1365-294X.2005.02553.x

Excoffier L, Laval G and Schneider S (2005). Arlequin (version 3.0): an integrated software package for population genetics data analysis. Evol. Bioinform. Online 1: 47-50.

Gupta P, Idris A, Mantri S, Asif MH, et al. (2012). Discovery and use of single nucleotide polymorphic (SNP) markers in Jatropha curcas L. Mol. Breed. 30: 1325-1335. http://dx.doi.org/10.1007/s11032-012-9719-6

Heller J (1996). Physic nut Jatropha curcas L. Promoting the conservation and use of underutilized and neglected crops. (Vol. 1). Bioversity International, Rome.

Hufford MB, Gepts P and Ross-Ibarra J (2011). Influence of cryptic population structure on observed mating patterns in the wild progenitor of maize (Zea mays ssp. parviglumis). Mol. Ecol. 20: 46-55.http://dx.doi.org/10.1111/j.1365-294X.2010.04924.x

Kaur K, Dhillon GPS and Gill RIS (2011). Floral biology and breeding system of Jatropha curcas in north-western India. J. Trop. For. Sci. 23: 4-9.

Liu K and Muse SV (2005). PowerMarker: an integrated analysis environment for genetic marker analysis. Bioinformatics 21: 2128-2129.http://dx.doi.org/10.1093/bioinformatics/bti282

Maghuly F, Jankowicz-Cieslak J, Pabinger S, Till BJ, et al. (2015). Geographic origin is not supported by the genetic variability found in a large living collection of Jatropha curcas with accessions from three continents. Biotechnol. J. 10: 536-551. http://dx.doi.org/10.1002/biot.201400196 
Na-Ek Y, Wongkaew A, Phumichai T and Kongsiri N (2011). Genetic diversity of physic nut (Jatropha curcas L.) revealed by SSR markers. J. Crop. Sci. Biotech. 14: 105-110. http://dx.doi.org/10.1007/s12892-011-0008-4

Negussie A, Achten WMJ, Verboven HAF, Hermy M, et al. (2014). Floral display and effects of natural and artificial pollination on fruiting and seed yield of the tropical biofuel crop Jatropha curcas L. GCB Bioenergy 6: 210-218.

Nietsche S, Vendrame WA, Crane JH and Pereira MCT (2013). Assessment of reproductive characteristics of Jatropha curcas L. in south Florida. GCB Bioenergy 6: 351-359. http://dx.doi.org/10.1111/gcbb.12051

Nunes CF, Ferreira JL, Generoso AL, Dias MSC, et al. (2013). The genetic diversity of strawberry (Fragaria ananassa Duch.) hybrids based on ISSR markers. Acta Sci. Agron. 35: 443-452. http://dx.doi.org/10.4025/actasciagron.v35i4.16737

Ovando-Medina I, Espinosa-García FJ, Núñez-Farfán JS and Salvador-Figueroa M (2011). State of the art of genetic diversity research in Jatropha curcas. Sci. Res. Essays 6: 1709-1719.

Pamidimarri DV, Sinha R, Kothari P and Reddy MP (2009). Isolation of novel microsatellites from Jatropha curcas L. and their cross-species amplification. Mol. Ecol. Resour. 9: 431-433.http://dx.doi.org/10.1111/j.1755-0998.2008.02471.x

Pandey VC, Singh K, Singh JS, Kumar A, et al. (2012). Jatropha curcas: a potential biofuel plant for sustainable environmental development. Renew. Sustain. Energy Rev. 16: 2870-2883. http://dx.doi.org/10.1016/j.rser.2012.02.004

Peakall R and Smouse PE (2006). GENALEX 6: genetic analysis in Excel. Population genetic software for teaching and research. Mol. Ecol. Notes 6: 288-295. http://dx.doi.org/10.1111/j.1471-8286.2005.01155.x

Pecina-Quintero V, Anaya-Lopez JL, Colmenero AZ, Garcia NM, et al. (2011). Molecular characterisation of Jatropha curcas L. genetic resources from Chiapas, México through AFLP markers. Biomass Bioenergy 35: 1897-1905. http://dx.doi. org/10.1016/j.biombioe.2011.01.027

Phumichai C, Phumichai T, Kongsiri N, Wongkaew A, et al. (2011). Isolation of 55 microsatellite markers for Jatropha curcas and its closely related species. Biol. Plant. 55: 387-390. http://dx.doi.org/10.1007/s10535-011-0061-3

Pritchard JK, Stephens M and Donnelly P (2000). Inference of population structure using multilocus genotype data. Genetics 155: 945-959.

Qiu LJ, Xing LL, Guo Y, Wang J, et al. (2013). A platform for soybean molecular breeding: the utilization of core collections for food security. Plant Mol. Biol. 83: 41-50.http://dx.doi.org/10.1007/s11103-013-0076-6

Raju AJS and Ezradanam V (2002). Pollination ecology and fruiting behaviour in a monoecious species, Jatropha curcas L. (Euphorbiaceae). Curr. Sci. 83: 1395-1398.

Salmaso M, Forestan C, Varotto S and Lucchin M (2009). Biodiversity of local Italian grapevine cultivars detected by SSR markers. Acta Hortic. 827: 137-142. http://dx.doi.org/10.17660/ActaHortic.2009.827.19

Sanou H, Angulo-Escalante MA, Martínez-Herrera J, Koné S, et al. (2015). Loss of genetic diversity of Jatropha curcas L. through domestication: implications for its genetic improvement: implications for its genetic improvement. Crop Sci. 55: 749-759. http://dx.doi.org/10.2135/cropsci2014.02.0165

Sharma A and Chauhan RS (2011). Repertoire of SSRs in the castor bean genome and their utilization in genetic diversity analysis in Jatropha curcas. Comp. Funct. Genomics 2011: 286089.http://dx.doi.org/10.1155/2011/286089

Sun QB, Li LF, Li Y, Wu GJ, et al. (2008). SSR and AFLP markers reveal low genetic diversity in the biofuel plant Jatropha curcas in China. Crop Sci. 48: 1865-1871. http://dx.doi.org/10.2135/cropsci2008.02.0074

Veasey EA, Piotto FA, Nascimento WF, Rodrigues JF, et al. (2011). Processos evolutivos e a origem das plantas cultivadas. Cienc. Rural 41: 1218-1228. http://dx.doi.org/10.1590/S0103-84782011000700018 